\title{
Probiotic properties of halophilic Bacillus strains enhance protection of Artemia culture against pathogenic Vibrio
}

\author{
Abdelkarim Mahdhi',*, Zeineb Hmila ${ }^{1}$, Kamel Chaieb ${ }^{1}$, Fathi Kamoun ${ }^{2}$, \\ Amina Bakhrouf ${ }^{1}$ \\ ${ }^{1}$ Laboratoire d'Analyse, de Traitement et de Valorisation des Polluants de l'Environnement et des Produits, \\ Faculté de Pharmacie de Monastir, 5000, Tunisia \\ ${ }^{2}$ Institut National des Sciences et Technologies de la Mer (INSTM), Monastir, 5000, Tunisia
}

\begin{abstract}
We characterized 3 halophilic Bacillus strains isolated from Tunisian hypersaline environments. Sequencing analyses showed that these bacteria corresponded to the genus Bacillus sp. Antagonism assay revealed that these strains have an inhibitory effect against tested pathogenic bacteria. Qualitative analysis of biofilm revealed that Bacillus strains were unable to produce slime. Furthermore, the investigated strains were fairly adhesive to polystyrene with values ranging from 0.10 to 0.32 at $595 \mathrm{~nm}$. Cell surface hydrophobicity values ranged between 10 and $42 \%$. Pathogenicity and toxicity assays demonstrated that the tested strains were not pathogenic or toxic to the host. Challenge tests performed with Artemia larvae provided evidence that the tested Bacillus strains enhance the protection of Artemia culture against pathogens. These strains are probiotic candidates for Artemia culture.
\end{abstract}

KEY WORDS: 16s RNA · Bacillus $\cdot$ Artemia $\cdot$ Antagonism $\cdot$ Adhesion $\cdot$ Hydrophobicity $\cdot$ Probiotic

\section{INTRODUCTION}

Infections caused by the Vibrionaceae family are an important problem in hatchery environments (Diggles et al. 2000) and a significant constraint to the development of aquaculture (Subasinghe et al. 2001). Infection occurs primarily through the food chain, particularly when Artemia are the food source (Muroga et al. 1987).

Different methods of controlling the microbial environment are being investigated. One of the methods gaining recognition is the use of probiotic bacteria (Gatesoupe 1999, Verschuere et al. 2000, Irianto \& Austin 2002a). To date the screening of probiotics has been pragmatic, and they are often assessed only on their ability to produce anti-microbial metabolites and reduce the risk of intestinal diseases and eliminate specific microbial disorders (Gaggìa et al. 2010).
Probiotics may protect their host from pathogens by producing metabolites which inhibit the colonization or growth of other microorganisms or by competing with them for resources such as nutrients or space (Balcázar \& Luna-Rojas 2007). The efficacy of a probiotic application depends on many factors (Gomez-Gil et al. 2000) such as application level, frequency of application and environmental conditions. In their study of trout probiotics, Irianto \& Austin (2002a) selected 4 of 11 bacteria which were deemed harmless to the fish following intra-peritoneal or intra-muscular injections. Zhou et al. (2009) reported that probiotic Bacillus coagulans SC 8168, supplemented as a water additive at a certain concentration, could significantly increase survival rate and some digestive enzyme activities in shrimp larvae. Mahdhi et al. (2010b) demonstrated that Pseudomonas stutzeri, Candida utilis and Bacillus sp. improve the conditions of 
Artemia culture and enhance protection against pathogenic bacteria. When these bacteria were administered as probiotics to the shrimp Penaeus monodon, growth and survival were improved and immunity was enhanced (Deng-Yu et al. 2009).

Various bacteria are able to produce extracellular polysaccharide, termed slime, which can reduce antibiotic susceptibility. These considerations explain the need for diagnostic methods which identify virulent bacteria strains by detecting their ability to produce slime (Christensen et al. 1982). Adhesive ability is considered an important selection criterion for probiotic bacteria, and also a prerequisite, because it offers beneficial microorganisms the capacity to colonize the intestinal tract and compete with micro-organisms (Mahdhi et al. 2010a,b). This property is determined by microbial cell surface hydrophobicity, recognized as one of the determining factors in microbial adhesion (Balebona et al. 1995). Various other factors may influence the processes of adhesion and colonization, reflecting properties related to the bacteria, to the epithelial cell surface, and to exogenous factors in the microenvironment in which the process occurs.

The aim of this study was to find more effective and environmentally-friendly probiotic strains, and obtain insight into their mode of action. This was achieved through the investigation of the probiotic properties of halophilic Bacillus strains and of their role in the protection of Artemia culture against pathogens.

\section{MATERIALS AND METHODS}

\section{Isolation and identification of bacterial strains}

Isolation and screening by plate method

Bacterial strains $(\mathrm{n}=20)$ were isolated from Artemia salina cultures obtained from different Tunisian hypersaline environments (Sebkha El Maleh: $33^{\circ} 32^{\prime} \mathrm{N}, 10^{\circ} 92^{\prime} \mathrm{E}_{\text {; }}$ Saltworks of Sfax: $34^{\circ} 72^{\prime} \mathrm{N}$, $10^{\circ} 73^{\prime} \mathrm{E}$, and $34^{\circ} 68^{\prime} \mathrm{N}, 10^{\circ} 62^{\prime} \mathrm{E}$ ). Water samples were collected and brought to the laboratory aseptically in an insulated container at $4^{\circ} \mathrm{C}$. The samples were serially diluted, plated on nutrient marine agar 2216 (Difco) and incubated at room temperature for 24 to $48 \mathrm{~h}$. The colonies from nutrient marine agar were replica plated on the Muller Hinton (MH) agar medium (Difco), swabbed against target bacterial strains and incubated at room temperature for $24 \mathrm{~h}$. The colonies showing a zone of clearance against pathogenic strains (Vibrio parahaemolyticus ATCC
17802, Vibrio alginolyticus ATCC 17749, Salmonella typhimurium ATCC 1408, Escherichia coli ATCC 35218, Staphylococcus aureus ATCC 25923, and Vibrio alginolyticus VA, isolated from infected fish; see Ben Kahla-Nakbi et al. 2006) were maintained separately in pure cultures (Hjelm et al. 2004).

Three strains that demonstrated an inhibitory effect against pathogens were retained and preserved at the laboratory and their purity routinely checked during the investigation. Stock cultures were frozen at $-80^{\circ} \mathrm{C}$ with $20 \%(\mathrm{v} / \mathrm{v})$ glycerol.

\section{DNA extraction, PCR and sequencing}

Total DNA was extracted from each strain according to the scheme described by Sambrook et al. (1989) and stored at $-20^{\circ} \mathrm{C}$. The 2 primers were B-K1/F $\left(5^{\prime}-\right.$ TCA CCA AGG CRA CGA TGC G-3') and B-K1/R1 (5'-CGT ATT CAC CGC GGC ATG-3') (Wu et al. 2006). Amplification was carried out using a reaction volume of $50 \mu \mathrm{l}: 2 \mu \mathrm{l}$ DNA, $0.2 \mathrm{mM}$ of each dATP, dGTP, dCTP and dDTP, $1 \times$ buffer solution, $1.5 \mathrm{mM}$ $\mathrm{MgCl}_{2}, 1.0 \mu \mathrm{M}$ of each primer (B-K1/F and B-K1/R1) and 1.0 unit of Taq DNA polymerase (Promega). The PCR program was conducted using a denaturation step of $3 \mathrm{~min}$ at $94^{\circ} \mathrm{C}$, followed by 25 cycles of $94^{\circ} \mathrm{C}$ for $30 \mathrm{~s}, 63^{\circ} \mathrm{C}$ for $30 \mathrm{~s}$ and $72^{\circ} \mathrm{C}$ for $2 \mathrm{~min}$, with an extension step at $72^{\circ} \mathrm{C}$ for $10 \mathrm{~min}$. PCR products were separated by $1.5 \%$ agarose gel electrophoresis. The sizes of DNA fragments were estimated using a $100 \mathrm{bp}$ DNA ladder (Promega). PCR products were purified using ExoSAP-IT (USB Corporation) according to manufacturer instructions and then sequenced in $2 \mathrm{di}-$ rections using dideoxy terminator cycle sequencing (Applied Biosystems 3730). Sequences were automatically aligned using Sequencher 4.1. (GeneCodes) and variable sites were checked visually for accuracy.

\section{Well diffusion agar assay (WDAA)}

Selected potential probiotic strains were tested for their antagonistic activity using the well diffusion agar assay (WDAA) against target strains used in the primary screening by the replica plate method. The pathogenic bacteria were grown in $10 \mathrm{ml}$ of nutrient broth and cultured for $24 \mathrm{~h}$ on nutrient agar at $30^{\circ} \mathrm{C}$. The common colonies from pure culture were suspended in $10 \mathrm{ml}$ of physiological medium, mixed well for $5 \mathrm{~min}$, and $1 \mathrm{ml}$ was spread over the agar plates. Potential probiotic strains were cultured in $10 \mathrm{ml}$ nutrient broth for $24 \mathrm{~h}, 100 \mu \mathrm{l}$ of the supernatant was 
introduced into the wells of the $\mathrm{MH}$ agar medium, and these were then incubated for $24 \mathrm{~h}$ at $30^{\circ} \mathrm{C}$. Antibacterial activity was defined as the diameter $(\mathrm{mm})$ of the clear inhibitory zone formed around the well (Vaseeharan \& Ramasamy 2003).

\section{Detection of slime production strain}

The ability of Bacillus strains to produce slime was tested according to the protocol described by Freeman et al. (1989). All tested bacteria were cultured on Congo red agar plates prepared by adding $0.8 \mathrm{~g}$ of Congo red (Sigma) and $36 \mathrm{~g}$ of saccharose (Labosi) to 11 of brain heart infusion agar (Bio-Rad). The Congo red stain was prepared as a concentrated aqueous solution and autoclaved separately at $121^{\circ} \mathrm{C}$ for 15 min and was added when the agar had cooled to $55^{\circ} \mathrm{C}$. Plates were incubated at room temperature $\left(37^{\circ} \mathrm{C}\right)$ for $24 \mathrm{~h}$ under aerobic conditions and subsequently overnight at room temperature. After incubation, pigmented colonies (generally black in color) were considered as slime-positive strains, whereas unpigmented bacteria (pinkish red, smooth colonies with a darkening at the centre) were interpreted as slime-negative (Sechi et al. 2002).

\section{Adherence to polystyrene surface}

The ability of Bacillus strains to form a biofilm on an abiotic surface was determined using a semiquantitative adherence assay on 96-well tissue culture plates (Nunc), as described previously (Mahdhi et al. 2010a,b). An overnight culture grown in Trypticase Soy Broth (TSB, Bio-Rad) at $37^{\circ} \mathrm{C}$ was diluted to 1:100 in TSB with $2 \%(\mathrm{w} / \mathrm{v})$ glucose. A total of $200 \mu \mathrm{l}$ of these cell suspensions was transferred to a U-bottomed 96-well microtiter plate (Nunc). Each strain was tested in triplicate. The plates were incubated aerobically at $37^{\circ} \mathrm{C}$ for $24 \mathrm{~h}$. The cultures were removed and the microtiter wells were washed twice with phosphate-buffered saline (PBS) $\quad(7 \mathrm{mM}$ $\mathrm{Na}_{2} \mathrm{HPO}_{4}, 3 \mathrm{mM} \mathrm{NaH} \mathrm{PO}_{4}$ and $130 \mathrm{mM} \mathrm{NaCl}$ at $\mathrm{pH}$ 7.4) to remove non-adherent cells and were dried in an inverted position. Adherent bacteria were fixed with $95 \%$ ethanol and stained with $100 \mu \mathrm{l}$ of $1 \%$ crystal violet (Merck) for $5 \mathrm{~min}$. The excess stain was rinsed off and the wells were washed 3 times with sterile distilled water. The water was then cleared and the microplates were air-dried. The optical density of each well was measured at $595 \mathrm{~nm}\left(\mathrm{OD}_{595}\right)$ using an automated Multiskan reader (GIO. DE VITA
E C). Adhesion ability was interpreted as strong $\left(\mathrm{OD}_{595} \geq 1\right)$, fair $\left(0.1 \leq \mathrm{OD}_{595}<1\right)$ or slight $\left(\mathrm{OD}_{595}<0.1\right)$ (Knobloch et al. 2001).

\section{Cell surface hydrophobicity analysis}

The hydrophobicity of Bacillus strains was evaluated by the microbial adhesion to solvent (MATS) test, which evaluates the affinity of the cells towards apolar solvents (hexadecane), as described by Bellon-Fontaine et al. (1996). Bacterial cells were harvested by centrifugation at $7000 \times g$ for $5 \mathrm{~min}$ and resuspended in a buffered salt solution ( $\mathrm{pH} 7.0)$ containing $\mathrm{Na}_{2} \mathrm{HPO}_{4}$ and $\mathrm{NaH}_{2} \mathrm{PO}_{4}\left(0.2 \mathrm{~mol} \mathrm{l}^{-1}\right)$ to a final density of $10^{9} \mathrm{CFU} \mathrm{ml}^{-1}$ (OD $=0.4$ at $600 \mathrm{~nm}$ ). This bacterial suspension was mixed with a solvent in the proportion of 1:6 (0.4/2.4 v/v) by vortexing for $3 \mathrm{~min}$ in order to form an emulsion. This mixture was then left for 30 min until the separation of 2 phases. The aqueous phase was recovered with a Pasteur pipette and the turbidity at $600 \mathrm{~nm}$ was measured. The percentage of adhesion was expressed as: $\%$ adhesion $=$ $\left[\left(\mathrm{OD}_{600}\right.\right.$ before mixing $-\mathrm{OD}_{600}$ after mixing $) / \mathrm{OD}_{600}$ before mixing] $\times 100$ (Wang \& Han 2007).

\section{Pathogenicity/toxicity towards Artemia}

Preparation of probiotic bacteria

Potential probiotic strains were cultured in $30 \mathrm{ml}$ of nutrient broth for $24 \mathrm{~h}$ at $37^{\circ} \mathrm{C}$. The broth was then transferred to a sterile $45 \mathrm{ml}$ centrifuge tube and centrifuged at $2000 \times g$ for $10 \mathrm{~min}$. The supernatant was poured into a sterile flask and kept at $4^{\circ} \mathrm{C}$, while the bacterial pellet was resuspended in sterile seawater (Niall 2004).

\section{Artemia gnotobiotic culture}

Experiments were performed with Artemia salina cysts collected from the Saltworks of Sfax $\left(34^{\circ} 43^{\prime} \mathrm{N}\right.$, $10^{\circ} 44^{\prime}$ E). Bacteria-free cysts and nauplii were obtained via decapsulation as described by Sorgeloos et al. (1986). Decapsulated cysts were washed with filtered and autoclaved sea water (FASW) over a $50 \mu \mathrm{m}$ net sterile filter. This procedure was repeated 9 times, using new FASW. After this step, washed decapsulated cysts were transferred to a sterile Falcon container with $30 \mathrm{ml}$ of FASW. The capped containers were placed and exposed to the constant incandescent 
light of a shaker incubator $\left(28^{\circ} \mathrm{C}, 120 \mathrm{rpm}\right)$. After 18 to $20 \mathrm{~h}$ of incubation, Artemia culture containing newly hatched nauplii was obtained.

\section{Pathogenicity/toxicity assay}

From the Artemia culture, $100 \mu \mathrm{l}$ volume containing 20 newly hatched nauplii was added to each well of a 96-well microtitre plate. $100 \mu \mathrm{l}$ of either probiotic bacterial suspension or the supernatant from each probiont was added to the Artemia. The control for the bacterial suspension was sterile sea water (CSSW), while sterile marine broth was used as the control for the supernatant (CSMB). After incubating the plate at $25^{\circ} \mathrm{C}$ for $24 \mathrm{~h}$, the number of dead Artemia in each well were counted. Then, $5 \mu \mathrm{l}$ of concentrated formalin $(100 \%)$ was added to each well to kill the live nauplii and the total number of Artemia per well were counted. All manipulations were carried out in triplicate under sterile conditions (Jann-Para et al. 2004).

\section{Challenge tests with Artemia nauplii}

To evaluate the effect of the bacterial strains on Artemia culture, 4 challenge tests were performed in triplicate under sterile conditions during $6 \mathrm{~d}$. A total of 10 axenic nauplii instars (II) obtained from Artemia gnotobiotic culture, as described above, were transferred to sterile Falcon containers with $30 \mathrm{ml}$ of FASW, together with the amount of feed scheduled for Day 1. All manipulations were carried out under a laminar flow hood and all necessary tools were previously autoclaved at $120^{\circ} \mathrm{C}$ for $20 \mathrm{~min}$. Test 1 was Artemia with pathogenic bacteria Vibrio alginolyticus VA (A+VA), Test 2 was Artemia with beneficial and pathogenic bacteria: $\mathrm{S} 1$ and $V$. alginolyticus VA $(\mathrm{A}+\mathrm{S} 1+\mathrm{VA})$. Test 3 was made with beneficial bacteria $\mathrm{S} 2$ and pathogenic bacteria strain $V$. alginolyticus VA $(\mathrm{A}+\mathrm{S} 2+\mathrm{VA})$. Test 4 was Artemia with strain $\mathrm{S} 3$ and $V$. alginolyticus VA (A+S3+VA). During challenge tests, beneficial bacteria $\mathrm{S} 1, \mathrm{~S} 2$ and $\mathrm{S} 3$ were added during the first $3 \mathrm{~d}$ and the pathogenic bacterial strain was provided on Day 3 only. The $V$. alginolyticus (VA) strain used for comparative purposes was isolated from infected fish (Ben Kahla-Nakbi et al. 2006). Potential probiotic and pathogenic bacterial suspensions were added at a density of $10^{7} \mathrm{CFU} \mathrm{ml}{ }^{-1}$ and $10^{6}$ $\mathrm{CFU} \mathrm{ml}{ }^{-1}$, respectively. The concentration of each bacterial strain was estimated through a regression analysis of the optical density of the pure culture. The number of $\mathrm{CFU} \mathrm{ml}{ }^{-1}$ was determined using Petri plates with marine agar. The number of swimming larvae was determined daily and the survival percentage was calculated. At the beginning and the end of each run, the absence of bacteria was monitored by transferring larvae and $100 \mu \mathrm{l}$ of water to Petri plates in triplicate with marine agar as described in Mahdhi et al. (2010a).

\section{Statistical analysis}

Survival percentages were arcsine transformed to satisfy normal distribution and homoscedasticity requirements. Differences in survival of Artemia cultured under different conditions were investigated with ANOVA and Duncan's test. Correlation between cell surface hydrophobicity and semi quantitative adherence assay was assessed using multivariate ANOVA. All statistical analyses were carried out at $\alpha=0.05$, using the software Statistica (version 5.5).

\section{RESULTS}

\section{Bacterial identification}

Based on the results of the amplification of the 16s RNA gene of Bacillus sp., the 3 tested strains yielded a PCR product with an amplicon around $1114 \mathrm{bp}$ long. These active probiotic bacterial isolates were subjected to the 16S rDNA sequence analysis. After comparison with previously available sequences in NCBI (National Center for Biotechnology Information) using BLAST (Basic Local Alignment Search Tool), they were identified as Bacillus sp. These sequences were deposited in GenBank under the accession numbers: HM117832 (S1); HM117833 (S2); HM117834 (S3).

\section{Antagonism assay}

The selected Bacillus strains had an antibacterial activity on Gram-positive and on Gram-negative bacteria with diameter of the inhibition zones ranging between 12 and $18.6 \mathrm{~mm}$ (Table 1).

\section{Slime production, adherence to polystyrene and hydrophobicity}

The isolated strains were non-slime producers and were fairly adhesive to polystyrene with values rang- 
Table 1. Antagonistic activity (mean $\pm \mathrm{SD}$, measured as diameter [mm] of the inhibition zone) of the selected Bacillus strains against Gram-negative and Gram-positive pathogens in the well diffusion agar assay

\begin{tabular}{|c|c|c|c|c|c|c|}
\hline $\begin{array}{l}\text { Bacillus } \\
\text { strains }\end{array}$ & $\begin{array}{l}\text { Salmonella } \\
\text { typhimurium } \\
\text { ATCC } 1408\end{array}$ & $\begin{array}{c}\text { Escherichia } \\
\text { coli } \\
\text { ATCC } 35218\end{array}$ & $\begin{array}{c}\text { Staphylococcus } \\
\text { aureus } \\
\text { ATCC } 25923\end{array}$ & $\begin{array}{c}\text { Vibrio } \\
\text { alginolyticus } \\
\text { ATCC } 17749\end{array}$ & $\begin{array}{c}\text { Vibrio } \\
\text { alginolyticus } \\
\text { VA }\end{array}$ & $\begin{array}{c}\text { Vibrio } \\
\text { parahaemolyticus } \\
\text { ATCC } 17802\end{array}$ \\
\hline S1 & $13.3 \pm 0.05$ & $14.6 \pm 0.05$ & $16 \pm 0.14$ & $18.6 \pm 0.11$ & $14.6 \pm 0.05$ & $13.6 \pm 0.05$ \\
\hline $\mathrm{S} 2$ & $12.6 \pm 0.05$ & $14.5 \pm 0.07$ & $15 \pm 0.05$ & $16 \pm 0.05$ & $12.3 \pm 0.05$ & $17.3 \pm 0.05$ \\
\hline S3 & $13 \pm 0.14$ & $12 \pm 0.0$ & $13 \pm 0.0$ & $12.5 \pm 0.07$ & $12.6 \pm 0.05$ & $14.3 \pm 0.05$ \\
\hline
\end{tabular}

ing from 0.10 to 0.32 at $595 \mathrm{~nm}$. The affinity to hexadecane (apolar solvent) was low, suggesting a hydrophilic character for the strain S1. Conversely, strains S2 and S3 were relatively hydrophobic (Table 2).

\section{Effect on Artemia culture}

The tested strains were not pathogenic or toxic to Artemia nauplii; survival rate of Artemia in the control treatments sterile sea water (CSSW) and sterile marine broth (CSMB) were $76 \%$ and $86 \%$, respectively. In treatments where Artemia nauplii were treated with probiont bacterial suspension (S1SW, S2SW and S3SW) and probiont culture supernatant (S1MB, S2MB and S3MB), survival rate ranged from $83 \%$ to $100 \%$. There was no significant difference between those treatments and the controls (Fig. 1).

Survival rate of Artemia larvae in treatment Artemia with pathogenic Vibrio alginolyticus VA $(\mathrm{A}+\mathrm{VA})$ was $0 \%$ at the end of treatment (Day 6) (Fig. 2). In the presence of potential probionts (S1, S2 and S3), Artemia nauplii challenged with VA resulted in higher survival rate (90 to $100 \%$ ) $1 \mathrm{~d}$ after addition of pathogenic bacteria (Day 4). However, at the end of the treatment (Day 6), survival rate ranged between 10 and $26 \%$. Compared to treatment $(\mathrm{A}+\mathrm{VA})$, a significant difference was found for Strains $\mathrm{S} 1$ and $\mathrm{S} 3$.

Table 2. Qualitative and quantitative estimation of biofilm formation on polystyrene microtiter plates by slime-negative Bacillus strains. OD595 $\geq 1$ : highly adherent, $0.1 \leq$ OD595 < 1: fairly adherent, OD595<0.1: slightly adherent

\begin{tabular}{|lccc|}
\hline Strain & $\begin{array}{c}\text { Phenotype } \\
\text { on CRA }\end{array}$ & $\begin{array}{c}\text { Adherence OD595 } \\
(\text { mean } \pm \text { SD) }\end{array}$ & $\begin{array}{c}\text { Cell surface } \\
\text { hydrophobicity } \\
(\%)\end{array}$ \\
\hline S1 & Orange & $0.29 \pm 0.28$ & $41.99 \pm 0.49$ \\
S2 & Pink & $0.32 \pm 0.09$ & $36.21 \pm 1.38$ \\
S3 & White & $0.11 \pm 0.07$ & $10.11 \pm 1.76$ \\
\hline
\end{tabular}

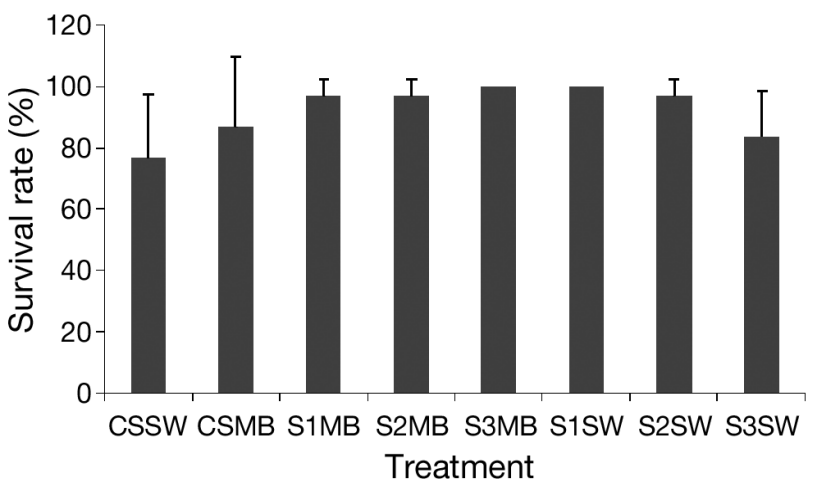

Fig. 1. Artemia salina. Survival rate of Artemia nauplii after $24 \mathrm{~h}$ exposure to bacterial pellet and their culture supernatant (mean $+\mathrm{SD})$. Controls were incubated in sterile seawater (CSSW) and sterile marine broth (CSMB). S1MB: culture supernatant of strain $\mathrm{S} 1 ; \mathrm{S} 2 \mathrm{MB}$ : culture supernatant of strain S2; S3MB: culture supernatant of strain S3. S1SW: probiotic bacterial suspension of strain $\mathrm{S} 1 ; \mathrm{S} 2 \mathrm{SW}$ : probiotic bacterial suspension of strain S2; S3SW: probiotic bacterial suspension of strain S3

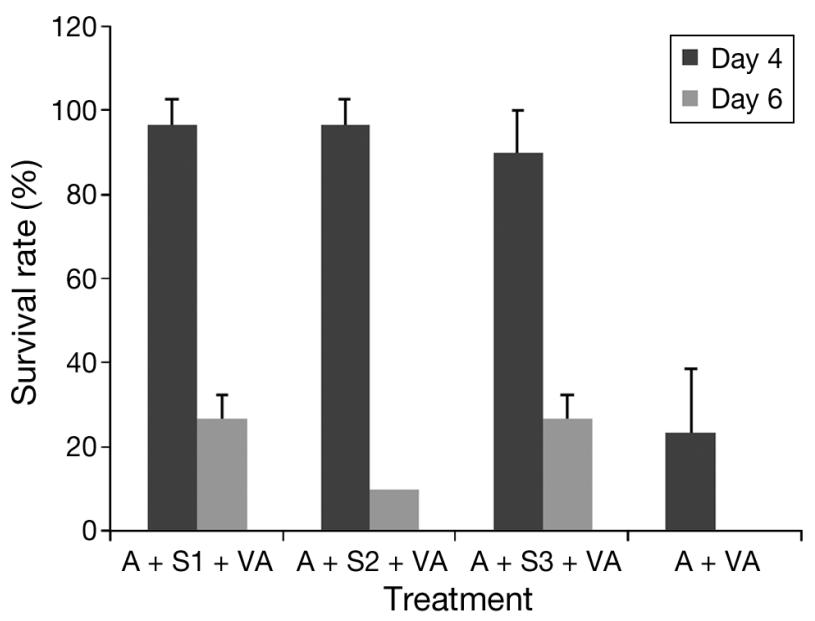

Fig. 2. Artemia salina. Survival rate (mean $+\mathrm{SD}$ ) of Artemia larvae after different treatments on Day 4 and Day 6: Artemia with strain S1 and Vibrio alginolyticus (A + S1 + VA); Artemia with strain S2 and Vibrio alginolyticus VA $(\mathrm{A}+\mathrm{S} 2+\mathrm{VA})$; Artemia with strain S3 and Vibrio alginolyticus VA (A + S3 +

VA); Artemia with Vibrio alginolyticus VA (A + VA) 


\section{DISCUSSION}

Our results indicate that Bacillus strains isolated from hypersaline environments have an inhibitory effect against the tested pathogenic bacteria and are able to enhance the protection of Artemia culture against pathogens. These findings can be explained by the antagonist ability of Bacillus strains to inhibit pathogenic bacteria, which can result from their artificial and temporary dominance when they are present in high concentrations. Also, the adhesive capacity of some microorganisms helps them to adhere to the intestinal tract and their effect on the digestive processes of aquatic animals can improve Artemia culture and protect against pathogens. Bacillus sp. are antagonistic against other microorganisms including fish and shellfish pathogenic bacteria (Gatesoupe 1999, Zhou et al. 2009, Deng-Yu et al. 2009), and significantly increase survival rate and some digestive enzyme activities in shrimp larvae (Zhou et al. 2009). The important role played by slime is further increased by its frequent association with reduced antibiotic susceptibility (Costerton et al. 1999). These considerations explain the need for diagnostic methods which identify virulent bacterial strains by correctly detecting their ability to produce slime. In this study, all the tested strains were non-slime producers and were fairly adherent to polystyrene microplates. Adherence ability to abiotic surfaces helps Bacillus strains to remain in the bacterial flora of the gut for several days and to be active during intestinal transit and participate in digestive processes, and thus aids in the elimination of potential pathogens and creation of a healthy environment for Dicentrarchus labrax larvae (Larpent et al. 1994). Selected probiotic bacteria, like Lactobacillus strains, have adhesive properties that enable them to inhibit and/or prevent the colonization of pathogens (Servin \& Coconnier 2003). Also, following adhesion to a surface, spores may germinate and vegetative cells may multiply. This can help this bacterium to compete with pathogens and ensure the necessary protection for the host (Zottola \& Sasahara 1994).

Pseudomonas stutzeri and Candida utilis are fairly adherent and can be used as probiotic candidates for Artemia culture (Mahdhi et al. 2010). Microbial cell surface hydrophobicity is one of the determining factors in microbial adhesion to bioremediation surfaces, a phenomenon commonly observed in natural and engineering systems (Wang et al. 2005a). It is generally accepted that hydrophobic interactions play an important role in the bioadhesion phenome- non. This finding can be explained by the significant correlation that we detected between the hydrophobicity of cells and the semi-quantitative adherence assay. Pathogenicity and toxicity assay show that the tested strains enhance Artemia nauplii resistance to pathogenic Vibrio. Marine Streptomyces strains and Aeromonas hydrophila also have a probiotic effect on the survival and growth of Artemia nauplii and are able to protect them from Vibrio sp. in culture (Das et al. 2010, Gunasekara et al. 2010). Also, it is possible that when pathogenicity is suppressed or lost, other factors such as growth rate or attachment ability may influence the microflora to the benefit of its host (Gomez-Gil et al. 2002, Liu et al. 2010). Mahdhi et al. (2010b), using mixture design have constructed a consortium of potential probiotic Bacillus strains able to protect gnotobiotic Artemia against pathogenic Vibrio. The same strategy was adopted by Avella et al. (2010) and demonstrated that the administration of a Bacillus probiotic mixture has a benefit for sea bream larvae in terms of stress response and growth.

In conclusion, the isolated bacterial strains are potential probiotic organisms in Artemia culture, and possibly for shellfish or fish larvae. Further studies, such as purification and characterization of antibacterial substances and extracellular products, would help to elucidate the mode of action of the beneficial effects of Bacillus strains.

Acknowledgements. The authors greatly acknowledge A. Garcia Saéz from the National Museum of Natural Science of Madrid, Department of Biodiversity and Evolutionary Biology, Spain, for his help in the molecular identification of bacterial strains. We also thank L. Nadia and D. Sabri from the University of Monastir, Tunisia, for their valuable comments on the English version of this manuscript.

\section{LITERATURE CITED}

Gunasekara RAYSA, Rekecki A, Baruah K, Bossier P, Van den Broeck W (2010) Evaluation of probiotic effect of Aeromonas hydrophila on the development of the digestive tract of germ-free Artemia franciscana nauplii. J Exp Mar Biol Ecol 393:78-82

Avella MA, Gioacchini G, Decamp O, Makridis P, Bracciatelli C, Carnevali O (2010) Application of multispecies of Bacillus in sea bream larviculture. Aquaculture 305:12-19

Balcázar JL, Luna-Rojas T (2007) Inhibitory activity of probiotic Bacillus subtilis UTM 126 against Vibrio species confers protection against vibriosis in juvenile shrimp (Litopenaeus vannamei). Curr Microbiol 55:409-412

Balebona MC, Morinigo MA, Faris A, Krovacek K, Mansson I, Bordas MA, Borrego JJ (1995) Influence of salinity and $\mathrm{pH}$ on the adhesion of pathogenic Vibrio strains to Sparus aurata skin mucus. Aquaculture 132:113-120 
Bellon-Fontaine M, Rault J, Van Oss C (1996) Microbial adhesion to solvents: a novel method to determine the electron-donor/electron acceptor or Lewis acid-base properties of microbial cells. Colloids Surf B Biointerfaces 7:47-53

Ben Kahla-Nakbi A, Chaieb K, Besbes A, Zmantar T, Bakhrouf A (2006) Virulence and enterobacterial repetitive intergenic consensus PCR of Vibrio alginolyticus strains isolated from Tunisian cultured gilthead sea bream and sea bass outbreaks. Vet Microbiol 117: 321-327

> Christensen GD, Simpson WA, Bisno AL, Beachey EH (1982) Adherence of slime-producing Staphyloccus epidermidis to smooth surfaces. Infect Immun 37:318-326

> Costerton JW, Stewart PS, Greenberg EP (1999) Bacterial biofilms: a common cause of persistent infections. Science 284:1318-1322

> Das S, Ward LR, Burke C (2010) Screening of marine Streptomyces spp. for potential use as probiotics in aquaculture. Aquaculture 305:32-41

> Diggles BK, Moss GA, Carson J, Anderson CD (2000) Luminous vibriosis in rock lobster Jasus verreauxi (Decapoda: Palinuridae) phyllosoma larvae associated with infection by Vibrio harveyi. Dis Aquat Org 43:127-137

Freeman DJ, Falkiner FR, Keane CT (1989) New method for detecting slime production by coagulase negative staphylococci. J Clin Pathol 42:872-874

Gaggìa F, Mattarelli P, Biavati B (2010) Probiotics and prebiotics in animal feeding for safe foods production. Int J Food Microbiol 141:S15-S28 doi:10.1016/j.ijfoodmicro 2010.02.031

> Gatesoupe FJ (1999) The use of probiotics in aquaculture. Aquaculture 180:147-165

Gomez-Gil B, Roque A, Turnbull JF (2000) The use and selection of probiotic bacteria for use in the culture of larval aquatic organisms. Aquaculture 191:259-270

Gomez-Gil B, Roque A, Velasco-Blanco G (2002) Culture of Vibrio alginolyticus $\mathrm{C} 7 \mathrm{~b}$, a potential probiotic bacterium, with the microalga Chaetoceros muelleri. Aquaculture 211:43-48

> Hjelm M, Bergh $\varnothing$, Riaza A, Nielsen J and 6 others (2004) Selection and identification of autochthonous potential probiotic bacteria from turbot larvae (Scophthalmus maximus) rearing units. Syst Appl Microbiol 27:360-371

Irianto A, Austin B (2002a) Probiotics in aquaculture. J Fish Dis 25:633-642

Jann-Para G, Schwob I, Feuillade M (2004) Occurrence of toxic Planktothrix rubescens blooms in Lake Nantua, France. Toxicon 43:279-285

Knobloch JK, Bartscht K, Sabottke A, Rohde H, Feucht HH, Mack D (2001) Biofilm formation by Staphylococcus epidermidis depends on functional RsbU, an activator of the sigB operon: differential activation mechanisms due to ethanol and salt stress. J Bacteriol 183:2624-2633

Larpent JP, Chateau N, Castellanos MI, Larpent JL (1994) La microflore intestinale et son rôle. In: Les probiotiques en Alimentation Animale et Humaine. Techniques at Documentation. Lavoisier, Paris

Liu KF, Chiu CH, Shiu YL, Cheng W, Liu CH (2010) Effects of the probiotic, Bacillus subtilis E20, on the survival, development, stress tolerance, and immune status of white shrimp, Litopenaeus vannamei larvae. Fish Shellfish Immunol 28:837-844

Mahdhi A, Chaieb K, Kamoun F, Bakhrouf A (2010a) Use of
Pseudomonas stutzeri and Candida utilis in the improvement of the conditions of Artemia culture and protection against pathogens. Braz J Microbiol 41:107-115

Mahdhi A, Harbi B, Ángeles Esteban M, Chaieb K, Kamoun F, Bakhrouf A (2010b) Using mixture design to construct consortia of potential probiotic Bacillus strains to protect gnotobiotic Artemia against pathogenic Vibrio. Biocontrol Sci Technol 20:983-996

- Muroga K, Higashi M, Keetoku H (1987) The isolation of intestinal microflora of farmed sea bream (Pagrus major) and black sea bream (Acanthopagrus schelegeli) at larval and juvenile stages. Aquaculture 65:79-88

Niall GV (2004) Towards the development of a protocol for the selection of probiotics in marine fish larviculture. PhD thesis, Rhodes University, Grahamstown

Sambrook J, Fritsch EF, Maniatis T (1989) Molecular cloning: a laboratory manual, 2nd edn. Cold Spring Harbor Laboratory Press, Cold Spring Harbor, NY

Sechi LA, Deriu A, Falchi MP, Fadda G, Zanetti S (2002) Distribution of virulence genes in Aeromonas spp. isolated from Sardinian waters and from patients with diarrhoea. J Appl Microbiol 92:221-227

Servin AL, Coconnier MH (2003) Adhesion of probiotic strains to the intestinal mucosa and interaction with pathogens. Best Pract Res Clin Gastroenterol 17: 741-754

Sorgeloos P, Lavens P, Leger P, Tackaert W, Versichele D (1986) Manual for the culture and use of brine shrimp Artemia in aquaculture. Laboratory of Mariculture, State University of Ghent, Belgium

Subasinghe RP, Bondad-Reantaso MG, McGladdery SE (2001) Aquaculture development, health and wealth. In: Subasinghe RP, Bueno P, Phillips MJ, Hough C, McGladdery SE, Arthur JR (eds) Aquaculture in the third millennium. Tech Proc Conf Aquaculture in the Third Millennium. NACA, Bangkok and FAO, Rome, Italy

Tseng DY, Ho PL, Huang SY, Cheng SC, Shiu YL, Chiu CS, Liu CH (2009) Enhancement of immunity and disease resistance in the white shrimp, Litopenaeus vannamei by the probiotic, Bacillus subtilis E 20. Fish Shellfish Immunol 26:339-344

Vaseeharan B, Ramasamy P (2003) Abundance of potentially pathogenic micro-organisms in Penaeus monodon larvae rearing systems in India. Microbiol Res 158:299-308

> Verschuere L, Rombaut G, Sorgeloos P, Verstraete W (2000) Probiotic bacteria as biological control agents in aquaculture. Microbiol Mol Biol Rev 64:655-671

- Wang YB, Han JZ (2007) The role of probiotic cell wall hydrophobicity in bioremediation of aquaculture. Aquaculture 269:349-354

> Wang YB, Xu ZR, Xia MS (2005a) Bacteria attached to suspended particles in northern white shrimp (Penaeus vannamei L.) ponds. Aquaculture 249:285-290

Wu XY, Walker MJ, Hornitzky M, Chin J (2006) Development of a group-specific PCR combined with ARDRA for the identification of Bacillus species of environmental significance. J Microbiol Methods 64:107-119

> Zhou X, Wang Y, Li W (2009) Effect of probiotic on larvae shrimp (Penaeus vannamei) based on water quality, survival rate and digestive enzyme activities. Aquaculture 287:349-353

Zottola EA, Sasahara KC (1994) Microbial biofilms in the food processing industry - should they be a concern. Int J Food Microbiol 23:125-148

Submitted: December 1, 2010; Accepted: July 27, 2011

Proofs received from author(s): September 21, 2011 